\title{
Adaptations of morphology, anatomy and phytochemical composition of leaves of Stratiotes aloides L. emergent forms
}

\author{
Cezary Toma $^{1 \star}$, Andrey Efremov ${ }^{2}$, Weronika Wojnar ${ }^{3}$ \\ ${ }^{1}$ Department of Carpology, Institute of Environmental Biology, Kazimierz Wielki University, Chodkiewicza 4, 80-064 Bydgoszcz, Poland, \\ e-mail: cezarytoma@poczta.onet.pl (*corresponding author) \\ ${ }^{2}$ Department of Biology, Omsk State Pedagogical University, Krasnyi Put 153/2, Omsk 644033, Russia \\ ${ }^{3}$ Department of Pharmacognosy and Phytochemistry, School of Pharmacy with the Division of Laboratory Medicine, \\ Medical University of Silesia in Katowice, Jagiellońska 4, 41-200 Sosnowiec, Poland
}

\begin{abstract}
Interdisciplinary research was carried out on the impact of climate on the diversity and morphology of Stratiotes aloides L. emergent forms' phenotype in various latitudes. The objectives of the research were: 1 . to determine whether the climate influences the diversity of emergent forms, 2. to determine the diversity of morphological and anatomical traits and chemical composition of $S$. aloides specimens in Poland and Russia, 3. to examine the content of, and determine the correlation between phenols, phenolic acids, flavonoids, anthocyanins, and tannins in S. aloides. The research demonstrated the substantial diversity of 13 morpho-anatomical traits, and 5 phytochemical traits, both between regions, and individual habitats. Principal Component Analysis (PCA) demonstrated different correlation patterns for the analysed substances between regions characterised by different temperature ranges. S.aloides shows substantial abilities to adapt in terms of structure and physiology to the aquatic environment in various climate zones.
\end{abstract}

Key words: macrophyte, water soldier, diversity, lake, morphology, anatomy, phytochemistry.

\section{Introduction}

Stratiotes aloides L. is a monocotyledonous aquatic plant, belonging to the monotypic genus Stratiotes L., and the family Hydrocharitaceae Juss. (Stevens 2001). This aquatic macrophyte is widely spread in Europe (Cook and Urmi-König 1983). Its distribution in Europe $(\mathrm{NBN})$ and Central Asia, where it is a native plant, and in Canada, where it is an invasive plant, has been the subject of frequent research (Snyder et al. 2016). Previous research focused on fruiting, sprouting (Smolders et al. 1995a, 1995b), growth dynamics, turions, morphological forms, and phenology (Glück 1936; Kornatowski 1976, 1979, 1983/1984, 1985; Renman 1989; Toma 2006; Efremov and Sviridenko 2008; Efremov 2016). No scientific papers were published on interdisciplinary research into $S$. aloides, i.e. its morphological, anatomical and phytochemical traits in various latitudes. Therefore, research was undertaken into S. aloides growing in northern Poland and Russia where climate factors substantially affect the final shape of the plant's phenotype and its chemical composition. The objective of the study was: $(i)$ to determine whether the climate influences the diversity of emergent forms, (ii) to determine the diversity of morphological and anatomical traits and phytochemical composition of $S$. aloides specimens in Poland and Russia, (iii) to examine the content of, and determine the correlation between, phenols, phenolic acids, flavonoids, anthocyanins, and tannins in S. aloides.

\section{Material and methods}

The research material was collected in Poland in the following habitats: 1. Pond (53.159968, 17.909755), 2. Lake (53.867803, 16.625061), 3. Oxbow lake (54.182029, 16.900349), and in Russia 4. River (56.079444, 74.644722), 5. Lake (57.403056, 67.053333), 6. Oxbow lake $(55.99583,47.214722)$. In total, 180 leaves were examined, including 90 leaves collected in Poland and 90 leaves from Russia in terms of their morphological and anatomical traits, together with $1 \mathrm{~g}$ of dry mass of leaves of the S. aloides emergent forms from each of the six locations. The specimens used in the research grew in 
Table 1. List of S. aloides traits and their abbreviated names

\begin{tabular}{|c|c|c|c|}
\hline No. & Features & Unit & Abbrev \\
\hline 1 & Length of the leaf & $\mathrm{cm}$ & LEN \\
\hline 2 & Width of the leaf cross-section at a height of $3 \mathrm{~cm}$ from the base & $\mathrm{mm}$ & WT3 \\
\hline 3 & Thickness of the leaf cross-section on the left side at a height of $3 \mathrm{~cm}$ from the base & $\mathrm{mm}$ & T3L \\
\hline 4 & Thickness of the leaf cross-section on the right side at a height of $3 \mathrm{~cm}$ from the base & $\mathrm{mm}$ & T3R \\
\hline 5 & Thickness of the leaf cross-section in the middle at a height of $3 \mathrm{~cm}$ from the base & $\mathrm{mm}$ & TV3 \\
\hline 6 & Cross-sectional area of the leaf $3 \mathrm{~cm}$ from the base & $\mathrm{mm}^{2}$ & PP3 \\
\hline 7 & Perimeter of the cross-sectional area of the leaf $3 \mathrm{~cm}$ from the base & $\mathrm{mm}$ & $\mathrm{O} 3$ \\
\hline 8 & Width of the leaf cross-section at a height of $10 \mathrm{~cm}$ from the base & $\mathrm{mm}$ & WT10 \\
\hline 9 & Thickness of the leaf cross-section on the left side at a height of $10 \mathrm{~cm}$ from the base & $\mathrm{mm}$ & T10L \\
\hline 10 & Thickness of the leaf cross-section on the right side at a height of $10 \mathrm{~cm}$ from the base & $\mathrm{mm}$ & T10R \\
\hline 11 & Thickness of the leaf cross-section in the middle at a height of $10 \mathrm{~cm}$ from the base & $\mathrm{mm}$ & TV10 \\
\hline 12 & Cross-sectional area of the leaf $10 \mathrm{~cm}$ from the base & $\mathrm{mm}^{2}$ & PP10 \\
\hline 13 & Perimeter of the cross-sectional area of the leaf $10 \mathrm{~cm}$ from the base & $\mathrm{mm}$ & 010 \\
\hline 14 & Total content of phenolic acids in emergent form leaves (mg of caffeic acid eq.) & $\mathrm{mg} \mathrm{g}^{-1}$ d.w. & TpaC \\
\hline 15 & Total content of phenols in emergent forms leaves (mg of gallic acid eq.) & $\mathrm{mg} \mathrm{g}^{-1}$ d.w. & TPC \\
\hline 16 & Total content of flavonoids in the leaves of the emergent forms (mg of quercetin eq.) & $\mathrm{mg} \mathrm{g}^{-1}$ d.w. & TFC \\
\hline 17 & Total content of tannins in the leaves of the emergent forms (mg of catechin eq.) & $\mathrm{mg} \mathrm{g}^{-1}$ d.w. & TTC \\
\hline 18 & Total content of anthocyanins in the leaves of emergent forms ( $\mathrm{mg}$ of cyaniding-3-glucoside eq. & $\mathrm{mg} \mathrm{g}^{-1}$ d.w. & TAC \\
\hline
\end{tabular}

water, in non-shaded spots, and the emergent parts of leaves constituted 30 to $35 \%$ of their total length. Leaves for the research were selected from each of the populations from the mid leaf whorl. Five specimens were collected from one habitat. Their leaves were further subjected to phytochemical examination. The material was collected in September 2017. The traits included in the examination and their abbreviations have been listed in Table 1. A total of 13 morpho-anatomical traits were examined. They were selected on the basis of earlier research on S. aloides (Toma 2006). The length of the leaves was measured with an accuracy of $1 \mathrm{~mm}$ and the remaining data with an accuracy of $0.01 \mathrm{~mm}$, determined with the use of the Met-Ilo 8 image analyser. In order to define the specimens' richness of diversity the modified Shanon-Wiener index was applied, which is used to determine biological diversity. Symbols applied in a formula for determining the diversity in research on S. aloides L. emergent specimens for a given habitat:

$$
H R=-\sum p_{i} \ln \left(p_{i}\right), p_{i}=n_{i} / N_{i},
$$

where $n_{i}$ stands for the number of specimens of a given type, and $N_{i}$ stands for the number of all the specimens will all traits. The data was analysed using the Statistica 12 and Excel computer software. The statistical data was calculated for individual habitats and Polish and Russian regions, i.e. minimum, maximum, variance, standard deviation and coefficient of variation. By carrying out the PCA mutual correlations were defined between phytochemical variables in various habitats in Poland and Russia.

Phytochemical analyses encompassed the determination of the total content of phenols, phenolic acids, flavonoids, anthocyanins, and tannins (Table 1). The plant material was subjected to extraction with the use of a methanol/water mixture $(80: 20 \mathrm{v} / \mathrm{v})$ for 30 minutes in a water bath under a reflux at the boiling point of the extractant. Each extract was filtered and subjected to spectrophotometric analysis. There were 5 repeated measurements for each of the markings. The results were averaged and presented as arithmetical means, per 1 gram of the dry mass of plant tissue. The total content of phenols was determined by taking $100 \mu \mathrm{L}$ extract which was made up to $3 \mathrm{~mL}$ with distilled water. Next, $0.5 \mathrm{~mL}$ Folin-Ciocalteu reagent was added. After a three-minute incubation $2 \mathrm{~mL} 20 \%$ solution of $\mathrm{Na}_{2} \mathrm{CO}_{3}$ was added and left for further incubation in a dark place for 60 minutes. Finally, $200 \mu \mathrm{L}$ solution from each sample was transferred to a 96-well microplate and absorbance measurement against a blank test at $750 \mathrm{~nm}$ was performed. The obtained results were referred to a gallic acid calibration curve. The results were expressed in mg gallic acid equivalent per gram of dry mass of plant tissue (Kaur and Kapoor 2002). In order to determine the total content of phenolic acids a $20 \mu \mathrm{L}$ extract was transferred to a 96-well microplate; $100 \mu \mathrm{L}$ distilled water, $20 \mathrm{~mL} 0.5 \mathrm{M} \mathrm{HCl}, 20 \mu \mathrm{L}$ Arnov reagent and $20 \mu \mathrm{L} 1 \mathrm{M} \mathrm{NaOH}$ were added. The solution was made up to $200 \mu \mathrm{l}$ with distilled water after which absorbance measurement against a blank test at $490 \mathrm{~nm}$ was performed. The results were referred to a calibration curve of caffeic acid and expressed in mg of caffeic acid equivalent per gram of dry mass of plant tissue (Gawlik-Dziki 2004). The total flavonoid content was determined in accordance with the protocol described by Samatha et al. (2012): $800 \mu \mathrm{L}$ distilled water and $60 \mu \mathrm{L} 5 \%$ solution of $\mathrm{NaNO}_{2}$ was added to a 200 
$\mu \mathrm{L}$ extract followed by a six-minute incubation. Next, $60 \mu \mathrm{L} 10 \% \mathrm{AlCl}_{3}$ was added and incubated again for 6 minutes. Finally, $80 \mu \mathrm{L} 4 \% \mathrm{NaOH}$ was added and made up with water to $2 \mathrm{~mL}$. After 15 minutes of incubation the $200 \mu \mathrm{L}$ reaction mixture was transferred onto a 96well microplate and read at 415 . The results were referred to a quercetin calibration curve and expressed in $\mathrm{mg}$ of quercetin equivalent per gram of dry mass of plant tissue (Samatha et al 2012). The total content of anthocyanins was tested by using a method based on the properties of anthocyanins, which change their colour in various $\mathrm{pH}$ environments: a $40 \mu \mathrm{L}$ extract was taken and placed in two separate wells of the 96-well microplate. $160 \mu \mathrm{L} \mathrm{pH}=1$ buffer solution was added to one of the wells, and $160 \mu \mathrm{L} \mathrm{pH}=4.5$ buffer solution was added to the other one. Absorbance measurement was performed after 20 minutes at $520 \mathrm{~nm}$ and at $700 \mathrm{~nm}$ reference wavelength. The obtained results were calculated using the molar extinction coefficient for cyanidin-3-glucoside $=26900 \mathrm{~L} \mathrm{~mol}^{-1} \mathrm{~cm}^{-1}$. The results were expressed as $\mathrm{mg}$ of cyanidin-3-glucoside equivalent per gram of dry mass of plant tissue (Lee et al. 2005). The total content of tannins was determined by applying a method involving the use of vanillin and hydrochloric acid: a $50 \mu \mathrm{L}$ extract was placed in a test tube. Next, $3 \mathrm{ml} 4 \%$ vanillin in methanol solution and $1.5 \mathrm{~mL}$ concentrated $\mathrm{HCl}$ was added. After 15 minutes of incubation, a $200 \mu \mathrm{L}$ mixture was transferred onto a 96-well microplate and measured at 510 wavelength. The results were referred to a catechin calibration curve and expressed as $\mathrm{mg}$ of catechin equivalent per gram of dry mass of plant tissue (Xu and Chang 2007).

\section{Results}

The diversity of specimens (HR) was calculated for S. aloides emergent forms for individual habitats in Poland and Russia (Fig. 1). In Poland, the diversity of specimens (1) in the pond, (2) lake, and (3) oxbow lake was similar. In Russia, the diversity of $S$. aloides emergent forms in the river (4) was lower by $25 \%$ when compared to habitats in Poland, and by $33 \%$ when compared to the remaining habitats in Russia. Lakes in Poland and

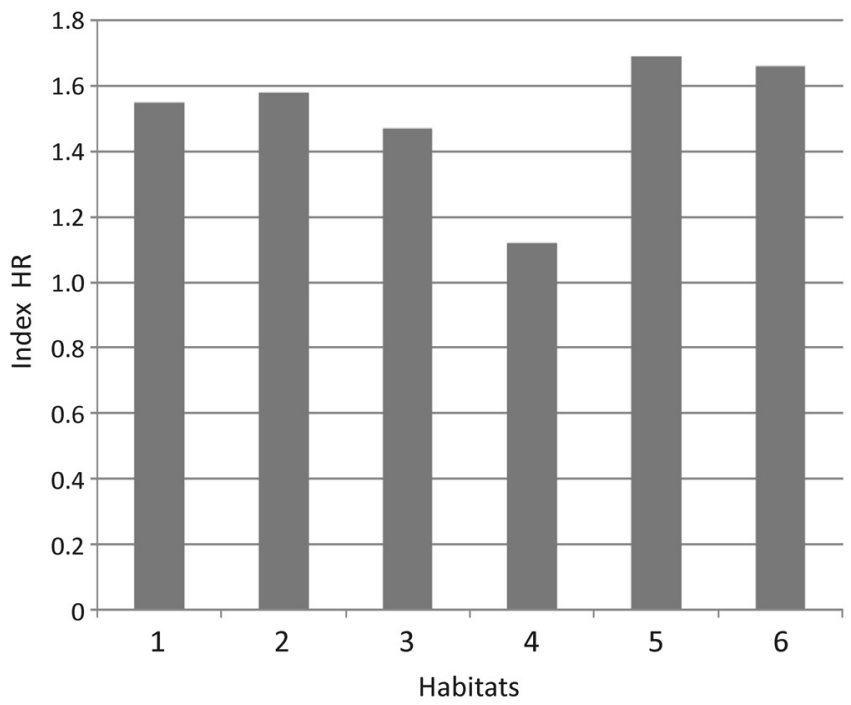

Fig. 1. Chart of Shannon-Wiener index for emergent forms of Stratiotes aloides L. in six habitats, 1 - Anthropogenic pond, Poland, 2 - Lake, Poland, 3 - Oxbow lake, Poland, 4 - River, Russia, 5 - Lake, Russia, 6 - Oxbow lake, Russia

Table 2. Descriptive statistics for S. aloides traits in all research sites in Poland and Russia Trait (abbreviations and units were given in Table 1)

\begin{tabular}{|l|r|r|r|r|r|r|}
\hline \multirow{2}{*}{ Trait } & \multicolumn{5}{|c|}{ Descriptive statistics } \\
\cline { 2 - 6 } & $\mathrm{N}$ & Average & Minimum & Maximum & Variance & \multicolumn{1}{c|}{ Stand. dev. } \\
\hline LEN & 180 & 41.30872 & 18.50000 & 64.50000 & 157.7735 & 12.56079 \\
\hline WT3 & 180 & 18.14961 & 5.32000 & 38.18000 & 52.9710 & 7.27812 \\
\hline T3L & 180 & 1.75121 & 0.25000 & 3.83000 & 0.5779 & 0.76017 \\
\hline T3R & 180 & 1.72582 & 0.24000 & 4.01000 & 0.5704 & 0.75525 \\
\hline TV3 & 180 & 4.32307 & 0.71000 & 7.63000 & 2.8511 & 1.68851 \\
\hline PP3 & 180 & 43.51572 & 8.05000 & 97.70000 & 379.5401 & 19.48179 \\
\hline O3 & 180 & 39.02283 & 3.92000 & 91.58000 & 404.2868 & 20.10688 \\
\hline WT10 & 180 & 19.60589 & 4.06000 & 45.96000 & 57.3414 & 7.57241 \\
\hline T10L & 180 & 1.30306 & 0.16000 & 2.86000 & 0.3734 & 0.61103 \\
\hline T10R & 180 & 1.28833 & 0.14000 & 2.67000 & 0.3730 & 0.61074 \\
\hline TV10 & 180 & 3.88067 & 0.24000 & 7.02000 & 2.6774 & 1.63627 \\
\hline PP10 & 180 & 43.66522 & 5.78000 & 97.32000 & 342.5296 & 18.50756 \\
\hline O10 & 180 & 35.97817 & 2.51000 & 78.91000 & 323.1494 & 17.97636 \\
\hline TpaC & 30 & 5.01825 & 3.00482 & 9.56199 & 3.5871 & 1.89397 \\
\hline TPC & 30 & 45.94947 & 35.75617 & 56.75089 & 32.5214 & 5.70275 \\
\hline TFC & 30 & 19.05428 & 11.51002 & 31.90803 & 34.3228 & 5.85857 \\
\hline TTC & 30 & 3.93354 & 2.97527 & 5.95054 & 0.7320 & 0.85559 \\
\hline TAC & 30 & 2.40186 & 0.58446 & 8.32161 & 5.3033 & 2.30289 \\
\hline
\end{tabular}




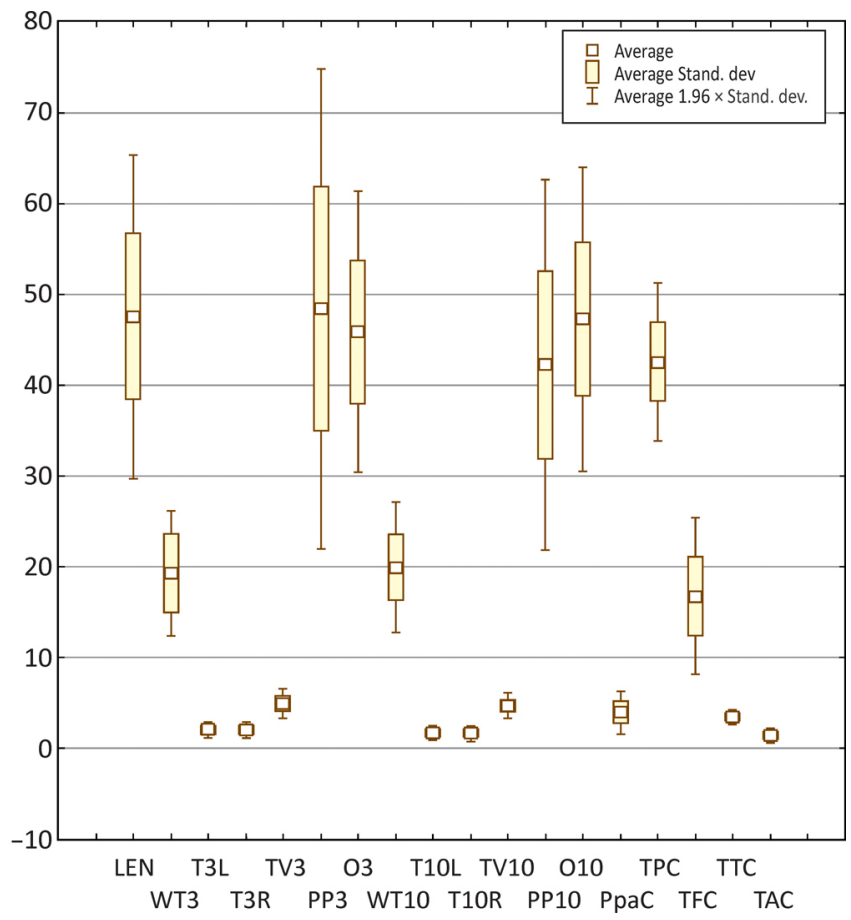

Fig. 2. A chart presenting average values for S. aloides traits in Poland

Russia can be characterised with the highest diversity of S. aloides emergent forms.

On all six research sites the length of $S$. aloides leaves ranged from $18.50 \mathrm{~cm}$ to $64.50 \mathrm{~cm}$, the width of leaves measured at $3 \mathrm{~cm}$ from the leaf base ranged from 5.30 $\mathrm{mm}$ to $38.18 \mathrm{~mm}$, and the width of leaves measured at $10 \mathrm{~cm}$ from the leaf base ranged from $4.06 \mathrm{~mm}$ to 45.96 $\mathrm{mm}$. The remaining data, including the minimum and maximum values, are presented in Table 2 . The data collected in Poland and in Russia were analysed separately in order to present differences depending on different geographical latitudes. The analysis of $S$. aloides leaf length demonstrated diversity as regards this trait and coefficients of variation. In Poland, the average length of leaves was $47.53 \mathrm{~cm}$, with min. length $-31 \mathrm{~cm}$, max. length $-64.50 \mathrm{~cm}$, variance -82.87 , standard deviation 9.10 , and the coefficient of variation -19.15 . The average values for Polish habitats are presented in a chart (Fig. 2). In Russia the average length of leaves of emergent forms was $37.24 \mathrm{~cm}$, with min. $-18.50 \mathrm{~cm}$, $\max .-58.20 \mathrm{~cm}$, variance -137.34 , standard deviation - 11.72 , and coefficient of variation -31.47 . The average values for Siberian

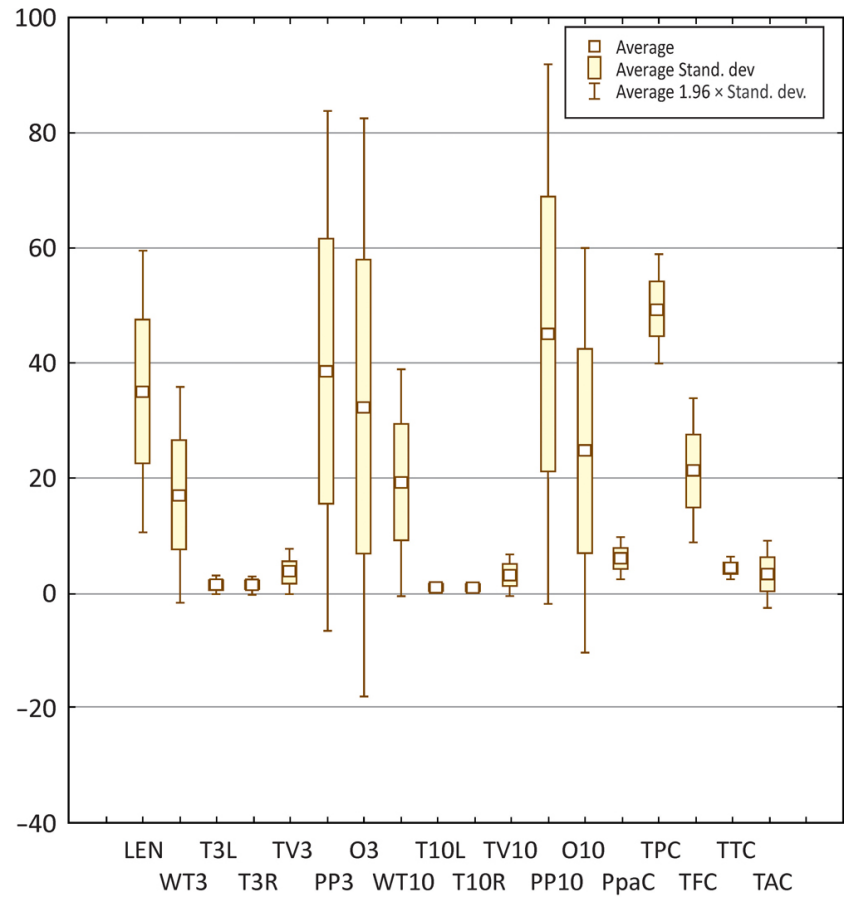

Fig. 3. A chart presenting average values for S. aloides traits in Russia

habitats are presented in a box-plot diagram (Fig. 3). In Poland, the average width of leaf cross-section at $3 \mathrm{~cm}$ from the base amounted to $19.32 \mathrm{~mm}$, with min. -12.46 $\mathrm{mm}$, max. $-27.78 \mathrm{~mm}$, variance -12.23 , standard deviation -3.49 , coefficient of variation - 18.10 , while in Russia the average width was $18.53 \mathrm{~mm}$, with min. -5.32 , max. -38.18 , variance -77.41 , standard deviation -8.79 , and coefficient of variation - 47.47. In Poland, the average width of leaf cross-section at $10 \mathrm{~cm}$ from the base amounted to $20.00 \mathrm{~mm}$, with $\mathrm{min}$. $-14.62 \mathrm{~mm}$, max. $29.93 \mathrm{~mm}$, variance -13.47 , standard deviation - 3.67 , and coefficient of variation - 18.35. In Russia, the average width was $21.02 \mathrm{~mm}$, with min. $-4.06 \mathrm{~mm}$, max. -45.96 $\mathrm{mm}$, variance -88.41 , standard deviation -9.40 , and coefficient of variation -44.72 .

It was found that in the oxbow lakes the average quantity of polyphenol compounds was higher than in lakes, both in Poland and in Russia. In Poland, the quantity of phenolic acids was higher in the oxbow lake by $80.25 \%$ when compared to the pond and by $75.23 \%$ when compared to the lake; the quantity of phenols was higher in the oxbow lake by $13.20 \%$ when compared to the pond,

Table 3. List of selected morphological and phytochemical traits of S. aloides leaves for Polish habitats (abbreviations and units were given in Table 1)

\begin{tabular}{|l|c|c|c|c|c|c|c|c|}
\hline \multirow{2}{*}{ Habitat } & \multicolumn{7}{c|}{ Traits } \\
\cline { 2 - 21 } & LEN & WT3 & WT10 & TpaC & TPC & TFC & TTC & 3.26 \\
\hline Pond & 52.54 & 16.18 & 17.33 & 3.14 & 40.06 & 12.29 & 1.25 \\
\hline Lake & 53.40 & 23.04 & 24.22 & 3.23 & 42.37 & 15.97 & 3.44 & 1.36 \\
\hline Oxbow lake & 36.66 & 18.74 & 18.45 & 5.66 & 45.35 & 22.21 & 3.48 & \\
\hline
\end{tabular}


Adaptations of morphology, anatomy and phytochemical composition of leaves of Stratiotes aloides L...

Table 4. List of selected morphological and phytochemical traits of S. aloides leaves for Russian habitats (abbreviations and units were given in Table 1)

\begin{tabular}{|c|c|c|c|c|c|c|c|c|}
\hline \multirow{2}{*}{ Habitat } & \multicolumn{8}{|c|}{ Traits } \\
\hline & LEN & WT3 & WT10 & TpaC & TPC & TFC & TTC & TAC \\
\hline River & 22.14 & 7.85 & 8.87 & 5.02 & 50.27 & 19.02 & 3.84 & 1.36 \\
\hline Lake & 47.95 & 28.80 & 29.74 & 4.47 & 46.23 & 15.30 & 3.94 & 1.19 \\
\hline Oxbow lake & 35.15 & 14.26 & 19.00 & 8.56 & 51.39 & 29.50 & 5.31 & 7.38 \\
\hline
\end{tabular}

and by $7.03 \%$ when compared to the lake; the quantity of flavonoids was higher in the oxbow lake by $80.71 \%$ when compared to the pond and by $39.07 \%$ when compared to the lake (Table 3 ). In Russia, the quantity of phenolic acids in the oxbow lake was higher by $70.51 \%$ when compared to the river and by $91.05 \%$ when compared to the lake; the quantity of phenols was higher in the oxbow lake by $2.22 \%$ when compared to the river and by $11.16 \%$ when compared to the lake; the quantity of flavonoids was higher in the oxbow lake by $55.09 \%$ when compared to the river and by $92.91 \%$ when compared to the lake; tannins were higher in the oxbow lake by $38.28 \%$ when compared to the river and by $34.77 \%$ when compared to the lake; anthocyanins were higher in the oxbow lake by $442.64 \%$ when compared to the river and by $520.16 \%$ when compared to the lake (Table 4).

PCA was performed for chemical variables in order to explain which of them were responsible for the largest degree of diversity in the phytochemical profile of S. aloides and what the correlations were between these compounds in Poland and in Russia. PCA for phytochemical variables in Poland (Fig. 4) demonstrated that the first component accounted for $48.59 \%$ of variance,

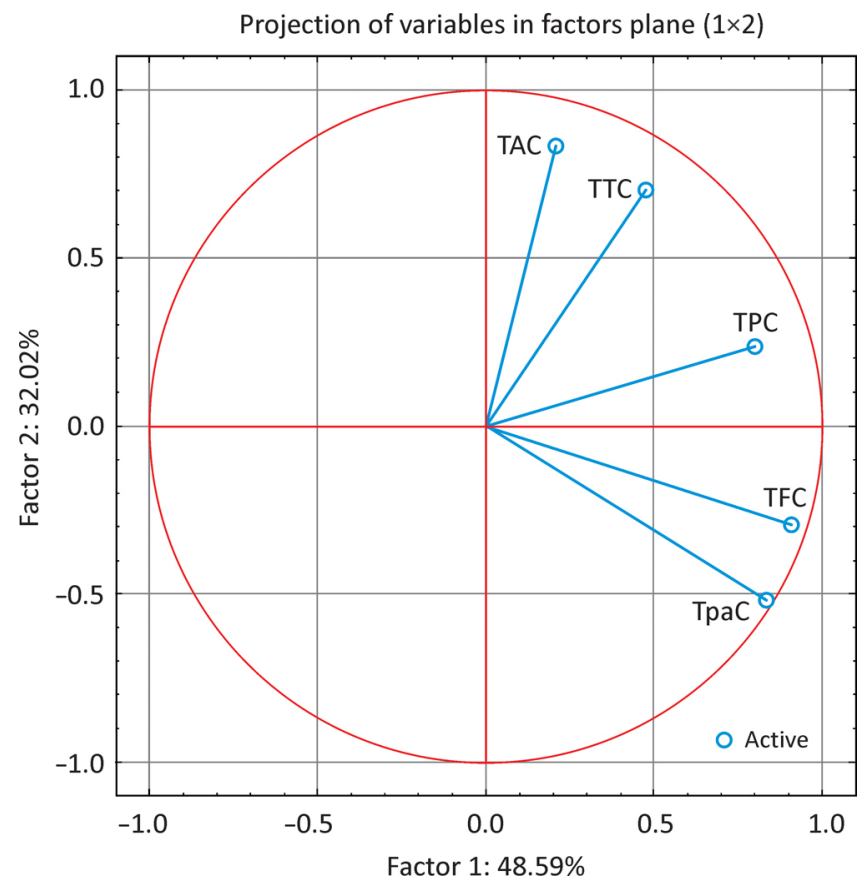

Fig. 4. PCA of pigments in S. aloides leaves in Poland whereas the second one accounted for $32.02 \%$ of variance. Thus, both components accounted for $80.61 \%$ of variance. The eigenvectors representing TFC (total flavonoid content) and $\mathrm{TpaC}$ (total phenolic acid content) variables were positioned close to the circumference of the correlation circle, which means that they were well accounted for by the two principal components and they are to a large extent responsible for the variability in $S$. aloides. The remaining variables, i.e. TPC (total phenolic content), TTC (total tannin content) and TAC (total anthocyanin content), were responsible for the variability to a smaller extent. The variables were positioned in the second and the fourth quadrant of the correlation circle. The TpaC and TFC variables were closely correlated, also showing a strong positive correlation with the first factor and a moderate negative correlation with the second factor. The TTC and TpaC variable eigenvectors were orthogonal, which means that no correlation between them was found. The TTC and TAC variables were also strongly correlated, while at the same time being weakly correlated with Factor 1 and strongly positively correlated with Factor 2 (Fig. 4). The PCA for chemical variables in Russia (Fig. 5) demonstrated that the first component

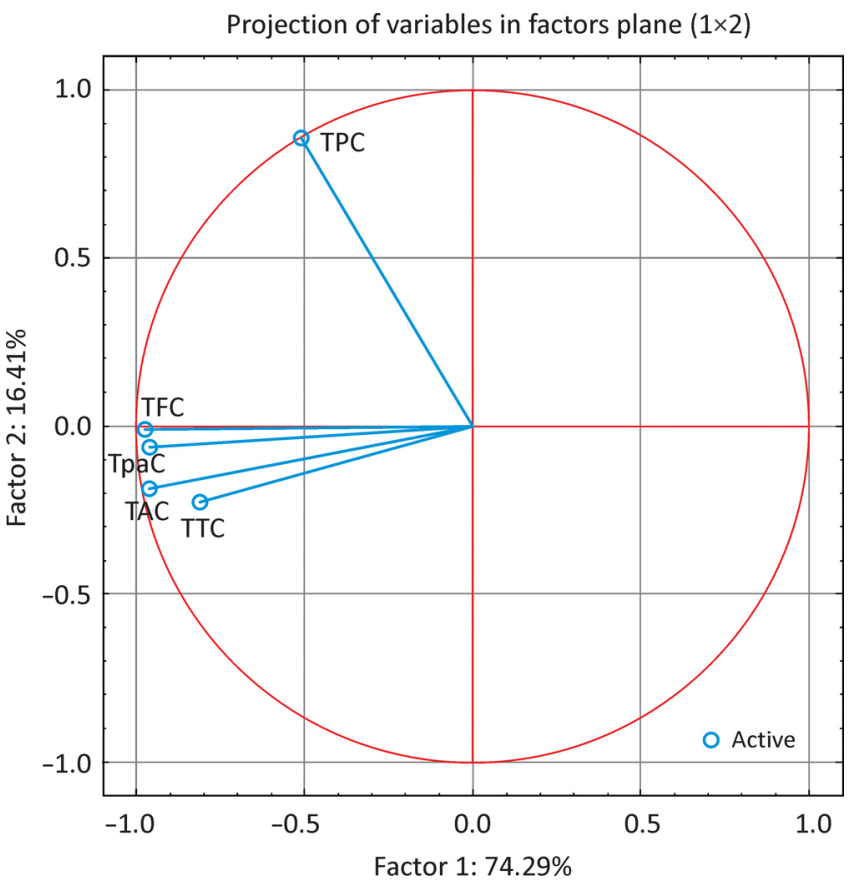

Fig. 5. PCA of pigments in S. aloides leaves in Russia 
accounted for $74.29 \%$ of variance, whereas the second one accounted for $16.41 \%$. Thus, both components accounted for $90.70 \%$ of variance. The eigenvectors representing the TPC, TFC, TAC and TpaC variables were positioned close to the circumference of the correlation circle, which means that they were well accounted for by the two principal components and they are, to a large extent, responsible for variability in S. aloides. The TTC variable accounts for the variability to a smaller extent than the foregoing variables. The variable eigenvectors are positioned in the first and the third quadrants of the correlation circle. The TPC, TFC, TAC and TpaC variables were closely correlated. The variables were negatively correlated with Factor 1 and weakly negatively correlated with Factor 2 (Fig. 5). The analysis shows that the correlations between phytochemical compounds in $S$. aloides in Poland and in Russia are substantially different.

\section{Discussion}

It has been proven that the diversity of traits of $S$. aloides is slightly greater in Poland than in Russia. However, the impact of climate on the diversity of the traits of $S$. aloides emergent forms is not significant in Poland or in Russia. On the other hand, the climate is a factor which considerably limits the sizes of leaves of $S$. aloides in Russia. S. aloides specimens reach smaller sizes in Russia, as confirmed by the research results. It has been found that habitat types substantially influence the diversity of $S$. aloides emergent forms, with the lowest diversity values in the river. Therefore, it can be concluded that the movement of water is a stressor significantly affecting this macrophyte. In general, the climate and habitat are factors affecting the diversity of the examined S. aloides specimens. The adaptation of S.aloides to an increased movement of water involves limiting the diversity of the studied traits and reduced size.

The adaptation of $S$. aloides leaves to habitats in Russia consists in a reduction of their average length by 10 $\mathrm{cm}$, whereas the anatomical adaptations include the changed geometry of the leaf base, which is on average wider in its lower part by $1 \mathrm{~mm}$ in Poland than in Russia, while the upper section of leaves is on average wider by $1 \mathrm{~mm}$ in Russia. Having compared Polish and Russian populations in terms of the leaf-blade thickness, it can be stated that in Russia leaf blades (at $3 \mathrm{~cm}$ from the base), are thinner by $38 \%$ and thinner in the middle part of the blades by $27 \%$; also, the leaf blades $(10 \mathrm{~cm}$ from the base) are thinner by $48 \%$ and thinner in their middle part by $36 \%$. In addition, the surface area of the leaf cross-sections and their perimeters are smaller in Russia than in Poland. However, given the differences between habitats, the thinnest leaf blades, with a thick- ness ranging from $0.51 \mathrm{~mm}$ to $0.53 \mathrm{~mm}$, were found in a river in Russia, whereas the thickness of leaf blades in lakes ranged from 2.32 to $2.38 \mathrm{~mm}$ both in Poland and in Russia.

Vascular plants produce a substantial number of organic compounds which are diverse in terms of their structure. Compounds such as carbohydrates, proteins, lipids, nucleic acids, amino acids or organic acids, which are referred to as primary metabolites, can be found in all plants in which they play key functions in plant organisms and their properties have long been known to scholars. There is also a large group of compounds the majority of which do not participate directly in the growth of a plant. Such substances are traditionally referred to as secondary metabolites. They have a variety of functions. However, not all of them have been thoroughly studied (Croteau et al. 2000). Secondary metabolites are responsible for, i.a., giving plants their specific pigmentation, smell and taste (Bravo 1998; Giada 2013).

Polyphenols are a large group of secondary metabolites. These compounds can be classified in terms of their origin and biological functions. One of the most frequently used classifications of polyphenols is their division by the aglycone structure. Over 8000 structures of polyphenolic compounds have been discovered, out of which flavonoids, with over 4000 structures described, are the most popular subject of research. In addition to flavonoids, scholars also distinguish procyanidins, which can condense into tannins and anthocyanins. The next group of polyphenolic compounds is composed of phenolic acids, which can be derivatives of both benzoic acid, and cinnamic acid (Tsao 2010).

Plants can synthesize phenolic compounds in reaction to the changing environment and conditions (Hutzler et al. 1998). Phenols are also responsible for passive and active resistance to, and protection from, pathogens, animals feeding on the plants and stress (Lodge 1991; Dudt and Shure 1994; Bennet and Wallsgrove 1994; Vergeer and van der Velde 1997; Richardson et al. 1999; Vermerris and Nicholson 2006). The oxbow lakes were characterised by relatively high densities of phytoplankton compared to their parent river (Azmi 2007). The increased contents of phenolic compounds in the oxbow lakes in Poland and Russia prove the presence of adaptation abilities in $S$. aloides in response to increased quantities of phytoplankton, zooplankton and bacteria, as they are usually higher in sediment water than in the water column (Gliwicz 2004). The concentration of phenolics is partly influenced by genetic background and partly by environmental factors (Connor et al. 2002; Howard et al. 2003).

To date there have been few studies on the chemical composition of S. aloides L. leaves. Previous phyto- 
chemical assays included only a comparative analysis of the total content of polyphenolic compounds in various types of leaves of selected aquatic plants (Smolders et al. 2000), and the qualitative composition of flavonoids found in the leaves of a given plant (Conrad et al. 2009). Species with submerged leaves showed a significantly lower phenolic content than species with emergent or floating leaves (Smolders et al. 2000). Our research covered only emergent forms of $S$. aloides in order to facilitate comparisons of the obtained results. It should also be noted that only emergent forms of $S$. aloides are present in shallowing oxbow lakes.

Given the participation of polyphenolic compounds in plant response to changing environmental conditions, their content can vary depending on climate, latitude and longitude, the altitude of the site where the plants are growing, temperature, humidity, exposure to UVB radiation, and numerous other factors, which have been proven for many other plants (Akerström et al. 2010; Josuttis et al. 2012; Martz et al. 2009; Tattini 2004; Treutter 2006; Zidorn 2010). Variabilities in phenolic contents were also found depending on a given plant's organ, time of collection, and the fertility of habitats (Dvoŕáková et al. 2018). In the present research, the first two factors did not impact on the results since the leaves of $S$. aloides were collected at the same time, whereas the fertility of habitats in Poland and Russia was not examined. Furthermore, polyphenolic compounds in aquatic plants are considered potential biomarkers which could be used for evaluating environmental changes (Ferrat 2003).

On the basis of the data obtained from Polish and Russian sites it can be inferred that the phytochemical variability in $S$. aloides $\mathrm{L}$. is related to the type of habitat (oxbow lake, lake, river). Differences in phytochemical profiles between site types can be attributed to, i.a., the microorganism flora or fungi colonising a given habitat, as it has been shown that polyphenolic compounds participate in protecting plants against pathogens (González-Lamothe et al. 2009; Lattanzio et al. 2006; Mierziak et al. 2014). The increased content of polyphenolic compounds, which was observed in Russian sites, might result from generally lower temperatures: minimum temperatures ranging from -17.9 to $-20.5^{\circ} \mathrm{C}$, with average annual temperatures ranging from 2.1 to $4.3^{\circ} \mathrm{C}$ in Russian sites in 2017 (FSRH 2018), as compared to temperatures recorded in Polish sites: minimum temperature amounted to $-6^{\circ} \mathrm{C}$, with an average annual temperature of $8^{\circ} \mathrm{C}$ in Bytów Lakeland in Poland in 2017 (IMGW 2018).

Zidron (2010), in his overview study on the impact of altitude on the content of secondary metabolites in flowers of Asteraceae, pointed out that temperature differences are one of the most important reasons for changes in the phytochemical profiles of the plants. In addition, the increased concentration of polyphenolic compounds, including phenolic acids and anthocyanins, was recorded in winter oilseed rape leaves subjected to low temperatures (Solecka et al. 1999). Similar results were presented for winter wheat, where a substantial increase in soluble polyphenols and flavonoids was recorded in leaves exposed to low temperatures (Olenichenko and Zagoskina 2005).

Studies focusing on phenolic concentrations in wetland macrophytes are very limited (Dvořáková 2018), as in European climate conditions they are limited to information from the Netherlands and northern Sweden (Hoorens et al. 2003; Dorrepall 2005; Aerts et al. 2006). In our study, we combined the morphological and anatomical aspects of the structure of leaves of $S$. aloides emergent forms with their diversity in the content of phytochemical compounds and their intercorrelations in various habitats in Poland and Russia with a view to obtaining a complete picture of changes taking place between the macrophyte and the environment.

\section{Conclusion}

The impact of the climate on the decreased diversity of emergent form specimens is insignificant, while it is significant in the case of the size of the phenotypes of S. aloides emergent forms. However, the type of habitat has a significant impact on the dimensions of leaves and their cross-sections, the leaf blade thickness, as well as on the diversity of S. aloides specimens. The climate and the type of habitat significantly influence the phytochemical compound values. Moreover, the correlation pattern is different for Poland and Russia.

\section{References}

Aerts R., van Logtestijn R.S.P., Karlsson PS., 2006, Nitrogen supply differentially affects litter decomposition rates and nitrogen dynamics of sub-arctic bog species, Oecologia 146(4): 652-658.

Akerström A., Jaakola L., Bång U., Jäderlund A., 2010, Effects of latitude-related factors and geographical origin on anthocyanidin concentrations in fruits of Vaccinium myrtillus L. (bilberries), J. Agric. Food Chem. 58(22): 11939-11945.

Azmi A.B., 2007, Plankton distribution and composition of oxbow lakes in Sabah [Master's thesis] University Malaysia Sabah, Kota Kinabalu, 125 pp.

Bennett R.N., Wallsgrove R.M., 1994, Secondary metabolites in plant defence mechanisms, New Phytol. 127(4): 617-633.

Bravo L., 1998, Polyphenols: chemistry, dietary sources, metabolism, and nutritional significance, Nutr. Rev. 56(11): 317-333. 
Connor A.M., Luby J.J., Tong C.B.S., Finn C.E., Hancock J.F., 2002, Genotypic and environmental variation in antioxidant activity, total phenolic content, and anthocyanin content among blueberry cultivars, J. Amer. Soc. Hort. Sci. 127(1): 89-97.

Conrad J., Förster-Fromme B., Constantin M.A., Ondrus V., Mika S., Mert-Balci F., Klaiber I., Pfannstiel J., Möller W., Rösner H., Förster-Fromme K., Beifuss, U., 2009, Flavonoid glucuronides and a chromone from the aquatic macrophyte Stratiotes aloides, J. Nat. Prod. 72(5): 835-840.

Cook C.D.K., Urmi-König K., 1983, A revision of the genus Stratiotes (Hydrocharitaceae), Aquat. Bot. 16(3): 213-249.

Croteau R., Kutchan T.M., Lewis N.G., 2000, Natural products (secondary metabolites), [in:] Buchanan B.B., Gruissem W., Jones R.L. (eds), Biochemistry and Molecular Biology of Plants, American Society of Plant Physiologists, Rockwill: 1250-1318.

Dorrepaal E., 2005, Plant growth-form and climate controls on production and decomposition in northern peatlands [Dissertation], Vrije Universiteit, Amsterdam, 174 pp.

Dudt J.F., Shure D. J., 1994, The influence of light and nutrients on foliar phenolics and insect herbivory, Ecology 75(1): 86-89.

Dvořáková Březinová T., Vymazal J., 2018, Phenolic Compounds in Wetland Macrophytes, Sci. Agric. Bohem. 49(1): 1-8.

Efremov A.N., 2016, Anatomy and morphology of vegetative organs and inflorescence of Stratiotes aloides L. (Hydrocharitaceae), Inland Water Biol. 9(1): 27-38.

Efremov A.N., Sviridenko B.F., 2008, The ecobiomorph of water soldier Stratiotes aloides L. (Hydrocharitaceae) in the west Siberian part of its range, Inland Water Biol. 1(3): 225-230.

Ferrat L., Pergent-Martini C., Roméo M., 2003, Assessment of the use of biomarkers in aquatic plants for the evaluation of environmental quality: application to seagrasses, Aquat. Toxicol. 65: 187-204.

[FSRH] Federal Service of Russia for Hydrometeorology and Monitoring Environment, 2018, Climate of Russia. Retrieved from http://aisori.meteo.ru/ClspR [accessed 7 February 2018].

Gawlik-Dziki U., 2004, Wpływ gotowania na skład i aktywność antyoksydacyjną kwasów fenolowych wyizolowanych z brokułu (The effect of cooking on composition and antioxidant activity of phenolic acids isolated from broccoli), Ann. UMCS E 59(4): 159-164 (in Polish, English summary).

Giada M.L.R., 2013, Food phenolic compounds: main classes, sources and their antioxidant power, [in:] Morales-Gonzalez J.A. (ed.), Oxidative stress and chronic degenerative diseases - A role for antioxidants, InTech, Rijeka: 87-112.

Gliwicz Z.M., 2004, Zooplankton, [in:] O’Sullivan P.E., Reynolds C.S. (eds), The Lakes Handbook. Vol 1, Blackwell Publishing, Oxford: 461-516.

Glück H., 1936, Pteridophyten und Phanerogamen unter gleichzeitiger Berücksichtigung der wichtigsten Wasser- und sumpfgewächse des ganzen Kontinents von Europa, [in:] Pascher A. (ed.), Die Süßwasser Flora Mitteleuropas, G. Fisher Verlag, Jena: 316-317 (in German).

González-Lamothe R., Mitchell G., Gattuso M., Diarra M.S., Malouin F., Bouarab K., 2009, Plant antimicrobial agents and their effects on plant and human pathogens, Int. J. Mol. Sci. 10(8): 3400-3419.

Hoorens B., Aerts R., Stroetenga M., 2003, Does initial litter chemistry explain litter mixture effects on decomposition?, Oecologia 137(4): 578-586.

Howard L.R., Clark J.R., Brownmiller C., 2003, Antioxidant capacity and phenolic content in blueberries as affected by genotype and growing season, J. Sci. Food Agric. 83(12): 1238-1247.

Hutzler P., Fischbach R., Heller W., Jungblut T.P., Reuber S., Schmitz R., Veit M., Weissenbock G., Schnitzler J.P., 1998, Tissue localization of phenolic compounds in plants by confocal laser scanning microscopy, J. Exp. Bot. 49: 953965.

[IMGW] Instytut Meteorologii i Gospodarki Wodnej (Institute of Meteorology and Water Management), 2018, Klimat Polski 1971-2017 (Climate of Poland 1971-2017). Retrieved from http://old.imgw.pl/klimat/ [accessed 7 February 2018].

Josuttis M., Carlen C., Crespo P., Nestby R., Toldam-Andersen T.B., Dietrich H., Krüger, E., 2012, A comparison of bioactive compounds of strawberry fruit from Europe affected by genotype and latitude, J. Berry Res. 2: 73-95.

Kaur C., Kapoor C.H., 2002, Antioxidant activity and total phenolic content of some Asian vegetables, Int. J. Food Sci. Technol. 37: 153-161.

Kornatowski J., 1976, Dynamics of Stratiotes aloides development, Pol. Arch. Hydrobiol. 23(3): 365-376.

Kornatowski J., 1979, Turions and offsets of Stratiotes aloides L., Acta Hydrobiol. 21(2): 185-204.

Kornatowski J., 1983/1984, Morphological forms of the water soldier (Stratiotes aloides L.), Acta Hydrobiol. 25/26: 145-156.

Kornatowski J., 1985, Phenological and morphometrical differentiation of the water-soldier (Stratiotes aloides L.), Acta Hydrobiol. 27: 33-47.

Lattanzio V., Lattanzio V.M.T., Cardinali A., 2006, Role of phenolics in the resistance mechanisms of plants against fungal pathogens and insects, [In:] Imperato F. (ed.), Phytochemistry: Advances in research, Research Signpost, Trivandrum: 23-67.

Lee J., Durst R.W., Wrolstad R.E., 2005, Determination of total monomeric anthocyanin pigment content of fruit juices, beverages, natural colorants, and wines by the $\mathrm{pH}$ differential method: collaborative study, J. AOAC Int. 88(5):1269-1278.

Lodge D.M., 1991, Herbivory on freshwater macrophytes, Aquat. Bot. 41: 195-224.

Martz F., Peltola R., Fontanay S., Duval R.E., Julkunen-Tiitto R., Stark S., 2009, Effect of latitude and altitude on the terpenoid and soluble phenolic composition of juniper 
(Juniperus communis) needles and evaluation of their antibacterial activity in the boreal zone, J. Agric. Food Chem. 57(20): 9575-9584

Mierziak J., Kostyn K., Kulma A., 2014, Flavonoids as important molecules of plant interactions with the environment, Molecules 19(10): 16240-16265.

[NBN] National Biodiversity Network, 2017, NBN Atlas website: Stratiotes aloides L. Retrieved from https://species.nbnatlas.org/species/NBNSYS0000002110 [accessed 7 February 2018].

Olenichenko N.A., Zagoskina N.V., 2005, Response of winter wheat to cold: production of phenolic compounds and 1-phenylalanine ammonia lyase activity, Appl. Biochem. Microbiol. 41(6): 600-603.

Renman G., 1989, Life history of two clons populations of Stratiotes aloides L., Hydrobiol. 185(3): 211-222.

Richardson C.J., Ferrell G.M., Vaithiyanathan P., 1999, Nutrient effects on stand structure, resorption efficiency, and secondary compounds in Everglades sawgrass, Ecology 80(7): 2182-2192.

Samatha T., Shyamsundarachary R., Srinivas P., Rama Swamy N., 2012, Quantification of total phenolic and total flavonoid contents in extracts of Oroxylum indicum L. kurz., Asian J. Pharm. Clin. Res. 5(Suppl 4): 177-179.

Smolders A.J.P., den Hartog C., Roelofs J.G.M., 1995a, Observations on fruiting and seed-set of Stratiotes aloides L. in the Netherlands, Aquat. Bot. 51(3): 259-268.

Smolders A.J.P., den Hartog C., Roelofs J.G.M., 1995b, Germination and seedling development in Stratiotes aloides L., Aquat. Bot. 51(3): 269-279.

Smolders A.J.P., Vergeer L.H.T., van der Velde G., Roelofs J.G.M., 2000, Phenolic contents of submerged, emergent and floating leaves of aquatic and semi-aquatic macrophyte species: why do they differ?, Oikos 91(2): 307-310.

Snyder E., Ardath F., Darbyshire S.J., 2016, Biology of invasive alien plants in Canada. 13. Stratiotes aloides L., Can. J. Plant Sci. 96(2): 225-242.
Solecka D., Boudet A.M., Kacperska A., 1999, Phenylpropanoid and anthocyanin changes in low-temperature treated winter oilseed rape leaves, Plant Physiol. Biochem. 37(6): 491-496.

Stevens P.F., 2001, Angiosperm Phylogeny Website. Version 14, July 2017 [and more or less continuously updated since]. Retrieved from http://www.mobot.org/MOBOT/ research/APweb/ [accessed 7 February 2018].

Tattini M., Galardi C., Pinelli P., Massai R., Remorini D., Agati G., 2004, Differential accumulation of flavonoids and hydroxycinnamates in leaves of Ligustrum vulgare under excess light and drought stress, New Phytol. 163(3): 547-561.

Toma C., 2006, Distribution and comparison of two morphological forms of water soldier (Stratiotes aloides L.): a case study on Lake Słosineckie Wielkie (NorthWest Poland), Biodiv. Res. Conserv. 3-4: 251-257.

Treutter D., 2006, Significance of flavonoids in plant resistance: a review, Environ. Chem. Lett. 4: 147-157.

Tsao R., 2010, Chemistry and biochemistry of dietary polyphenols, Nutrients 2(12): 1231-1246.

Vergeer L.H.T., van der Velde G., 1997, Phenolic content of daylight-exposed and shaded floating leaves of water lilies (Nymphaeaceae) in relation to infection byfungi, Oecologia 112(4): 481-484.

Vermerris W., Nicholson R., 2006, The role of phenols in plant defense, [in:] Vermerris W., Nicholson R (eds), Phenolic compound biochemistry, Springer, Dordrecht: 211-234.

Xu B.J., Chang S.K.C., 2007, Comparative study on phenolic profiles and antioxidant activites of legumes as affected by extraction solvents, J. Food Sci. 72(2): 159-166.

Zidron C., 2010, Altitudinal variation of secondary metabolites in flowering heads of the Asteraceae: trends and causes, Phytochem. Rev. 9(2): 197-203. 